\title{
Recent Progress in Marine Machinery
}

\section{T. J. Haddy R.N.}

To cite this article: T. J. Haddy R.N. (1893) Recent Progress in Marine Machinery, Royal United Services Institution. Journal, 37:179, 67-77, DOI: 10.1080/03071849309417696

To link to this article: http://dx.doi.org/10.1080/03071849309417696

\section{曲 Published online: 11 Sep 2009.}

Submit your article to this journal

Џll Article views: 4

Q View related articles ¿ 


\section{RECENT PROGRESS IN DIARINE MIACHINERY}

\section{(Translated from the "Rirista Marittina" for September," 1892, by T. J. Havdr, R.N.}

\section{Actual. Practice followed in the Construction and Working of the Mrotive Apparalus of Slips of War.}

Forced draught, high boiler pressures, multiplo expansion, and high speed of revolution introduced in the motive machinery of ships of war in order to economizo weight, space, and fuel hare produced inconveniences, neither few nor slight, in order to lessen or eliminate which modifications and improvernents have been rendered necessary in the engines and boilers; other improrements have been suggested by the progress of science and of the mechanical arts and by the continued study brought to bear on marine nuchinery, and of these improvements from the abore sources I propose to make a summary.

Boiler Construction.-No considerable change has taken placo in the general design of the boiler, bat in the details only, and on which I will now remark. First of all I may mention that tho reduction of the tesi pressuro has resulted in a sensible reduction in the thickness and weight of the boilers. In the mercantile marine the proof pressure is now, as it was in tho past, twice the working pressure of the boiler, whatever that pressure might be, and the thickness of the plates and stays, both for the shell and the parts exposed to the action of fire, are calculated on the proof pressure so established; on the other hand, in the Fnglish Navy, and later in ours, for boilers witl over 90 lbs. working pressure it has been considered sufficient to limit the proof pressure to the pressure on the safety valvo $p l u s$ a constant of $90 \mathrm{lbs}$, and to calculato the thickness of the shell plates from this basis. The motives which have suggested this measure are-

Ist. That with the old rule, the greater the working pressure the greater the factor of safety became, with the result that the latter was excessive in the case of modern boilers with high pressures.

2nd. That this margin of resistance was uselessly ligh for the shells of boilers, which are not exposed to the action of heat, and the strength of which can be precisely ascertained from reliable data.

3rd. That the high proof pressure necessitated the employment of very thick plates for the shells of ordinary return tube marine boilers, which plates are difficult to produce and to work, and which do not present, especially in finished work, the same guarantee of good quality and solidity which thinger plates afford. 
4th. That with the now rule, as the thickness of the shell plates is reduced about 18 per cent., there is a considorable saving in the weight of the boiler.

5 th. In conclusion, the new rale has the sanction of experience, having been for some time in general use for locomotive work. This new rule, which bas also been adopted by other navies, has given good results, and it is probable that it will also be sliortly accepted by the Board of 'I'rade, Lloyd's Register, the Burcan Veritns, Registro Italiano, and other institutions which rogulate boiler con. struction. On this question the late Richard Sennelt contribated an important article included in the "Trnnsactions of the Institution of Naral Architects" for 1888.

Forced Draught.-Forced combnstion in boilers naturally lins limits which it is not possiblo to surpass, and which depend on the capacity of the heating surfaces to transmit to the water the heat from the furnace, and to resist without clamage the eleration of temperature in tho plates. But lately, during the trials of new machinery in the Fnglish Navf, serious defects hare been manifested in the boilers run under matural draught, and in a degree never known before forced draught was introduced. These defects generally consisted in sudden leaks and barsis of water and steam from around the cads of the tubes in the tube plates exposed to the fire.

These defects hare oceurred in double-ended boilors with combustion chambers common to all the furnaces (that is, not having separate chambers with water spaces between then and plates to absorb the heat), in addition to which the spaces between tho different nests of tubes were somewhat confined. Accurate theories and experiments bave induced the belief that the defect is principally due to the structure of tho boilers of this class, in which there is a deficiency of surface in the combustion chamber to absorb the heat of combustion in conjunction with a defectire circulatio of the water in contact with the tabe plate, which favours the formation of a stratum of rapour in the neighbourhood of this plate, little fitted to extract the heat from it. It seems, in fact, that under forced druaght the intensits of the heat thrown on the tube plates, and on the ends of the tubes, is such that theso parts aro soon injured unless kept cool by an abundant afflax of water, or in some other way. This explanation has been confirmed by experience; the defective boilcrs have been improved by leaving out some vertical rows of tubes, in order to improve the circulation of tho water, and later boilers having been construeted with a separato combustion chamber to ench furnace with tho different nests of tubes well separated, have giren results under forced draught in crery respect satisfactory. In the English $\mathrm{Navy}$ siugle-onded hoilers are much in faronr, and are preferred to tho double-ended t5pe, because it is thought that in the first the circulation of the water is moro regalar. This may be true, but to me it appears donbtful if on the whole this preference is justified, sinco for the benefit of a regularity in the circulation of the water, which could be obtained by other means, the greater advanticge is giren up of.haring the steam genernted in a few boilers of large power to subdivide it 
among double the number of boilers of smaller power, the collective munacgement of which must necessarily be more difficnlt.

Hero it is not out of place to note the influenco which tho combination of the two causes above cited had on the bad results obtained with double-ended boilers with combustion chambers commou to all the furnaces, since by the suppression or amelioration of one of them tho lamentablo defects were sensibly diminished, whilst it cannot bo said that one cause, that is, the deficiency in tho circulation of the water in contact with the tube plates of the combustion chamber, has the greatest influence in the phenomenon, becanso there are boilers, for example, those of the torpedo-boats of the "Schichau" type, which havo giren splendid results under forced draught, and in which tho tubes are so close together as to undoubtedly make tho circulation difficult and limited. But in these boilers the furnaces are very wide and present a large surface for the reception of heat from the fire beforo the flames strike against the tubo plates into which the tubes are screwed and beaded orer; this mas explain tho good results obtained. Forced draught in boilers has been. the suhject of an interesting communication from Mrr. A. F. Yarrow, at the Institation of Naral Architects in March, 1891, in which ho has shown the necessity of giving the grcatest possible liberty of expansion to the rarious parts of the boiler, and also to contraction and inodification of form under the changes of temperature. Tho observations of Mr. Yarrow refer more particularly to boilers of tho locomotive type, but they havo mnch value also for those of the ordinary marino type, and of those I shall treat farther on.

It is probable that it may soon be possible to prodace a type of boiler for sea servico that in conjunction with other requisites will possess that of being able to withstand a highly forced combustion, above what has jet been attempted, but in the meantine it las been considered advisable in England to abundon the common combustion chamber type, and to abstain from forcing tho boilers bejond the limit which also in the mercentile marine has been found possiblo and practicable. This limit for ordinary boilers corresponds to a dercloped power not exceeding by more than $a$ third that which tho same boilers conld develop under an air pressure equal to one inch of water. It is well to note that the ase of forced draught within moderate limits is gradually extending in the merchant service, by which is obtained not only economy of weight and space, and greater independence of atmosplieric conditions, but also economy in fuel consumption, which in many cases, with a proper proportion of grato surface. has reached 15 por cent., and with the adrantago that coal of an inferior quality can be used with more cconomy than with natural draught. Amongst the rarious systems of forced draught in use, viz., with closed stokeholds, closed farnaces, and aspirntors in the funnel, it is not very certain which merits the profercuce. Forced draught with closed stokcholds is rory simple in action and has been as yet the plan most generally adopted; but it has the defect that it prevents or renclers very difficult communication betreen thestokeholds, engine rooms, and other parts of the ship, con- 
sequently exposing the personnel to grenter risks in the event of accident to the boilers, steam pipes, or loull of the ship. On the other hand, it has the advantage that it maintains a supply of fresh air in the stokeholds, and so the work of the stokers is rendered less arduous than with other systems. This system has been applied to nenrly all the new ships of our Navg. The system of forced dranght with closed furnaces is gaining ground, from the fact that it allows as free communication between the stohelolds, engine rooms, and other parts of the ship as under natural draught. This sfstem also lends itself more readily than the first mentioned to the device of warming the air previous to its supply to the furnaces, resulting in cconomy, (althongh slight) in fuel and better preserration of tho boiler. It would seem to be a fact that in boilers forced in this manner, on account of the reduced current of cold air which is admitted to the furnaces during the management of the fircs, leaks at the tubes aro neither so frequent nor serious. 'This fact is more evident still in boilers worked with liquid fuel, and in which, in spito of the quick combustion and very high temperature, leaks of tho tubes are of rare occurrence on account of the great regalarity and uniformity of the combustion and tho complete absence of currents of cold air. The closed furnaco system has been applied with complete success in our own Navy in some of the torpedo-cruisers of the "Partenope "type, or the torpedo-catchers of the "Aquila" type, and in all the sea-going torpedo-bonts. The third system is as yet in the experimental stage, not having entered into the practical, thero being still many difficalties in the way of its adoption. It appears, however, from the point of view of the preservation of the boiler that it would be well if it could be employed.

Particulars of Boiler Construction.-The rules actually followed in the details of boiler construction, the fruit partly of recent experiments made for the purpose of efrminating defects or finding the cause of them, are the following. 'They refer especially to boilers designed to work under forced draught.

Furnaces and Combustion Chambers.-In the ordinary marine boiler it is necessary that each furnace should have an ample combustion chamber to itself, scparated from those of the other furnaces by its metal sides and the body of water between them. Large boilers having four furnaces on the samo front are an exception to this rule, as by reason of space it is preferable to couple two farnaces to one combustion chamber.

In ordinary marine boilers the length of the combustion chamber in the direction of the axis of the furnace, if possible, should not be less than nine-tenths of the diameter of the furnace. It is a good rule, also, to protect the lower part of the combustion chamber opposito the tube plate with refractory brichwork. In boilers of the locomotive type, of large dimensions, in order to afford a larger surface to alssorb the radiant heat of the furnace, it is considered better to divide the furnace longitudinally into two parts with a vertical body of water between them. In these boilers the furnaces should be long, whether there are two or one, so that the tabo plates 


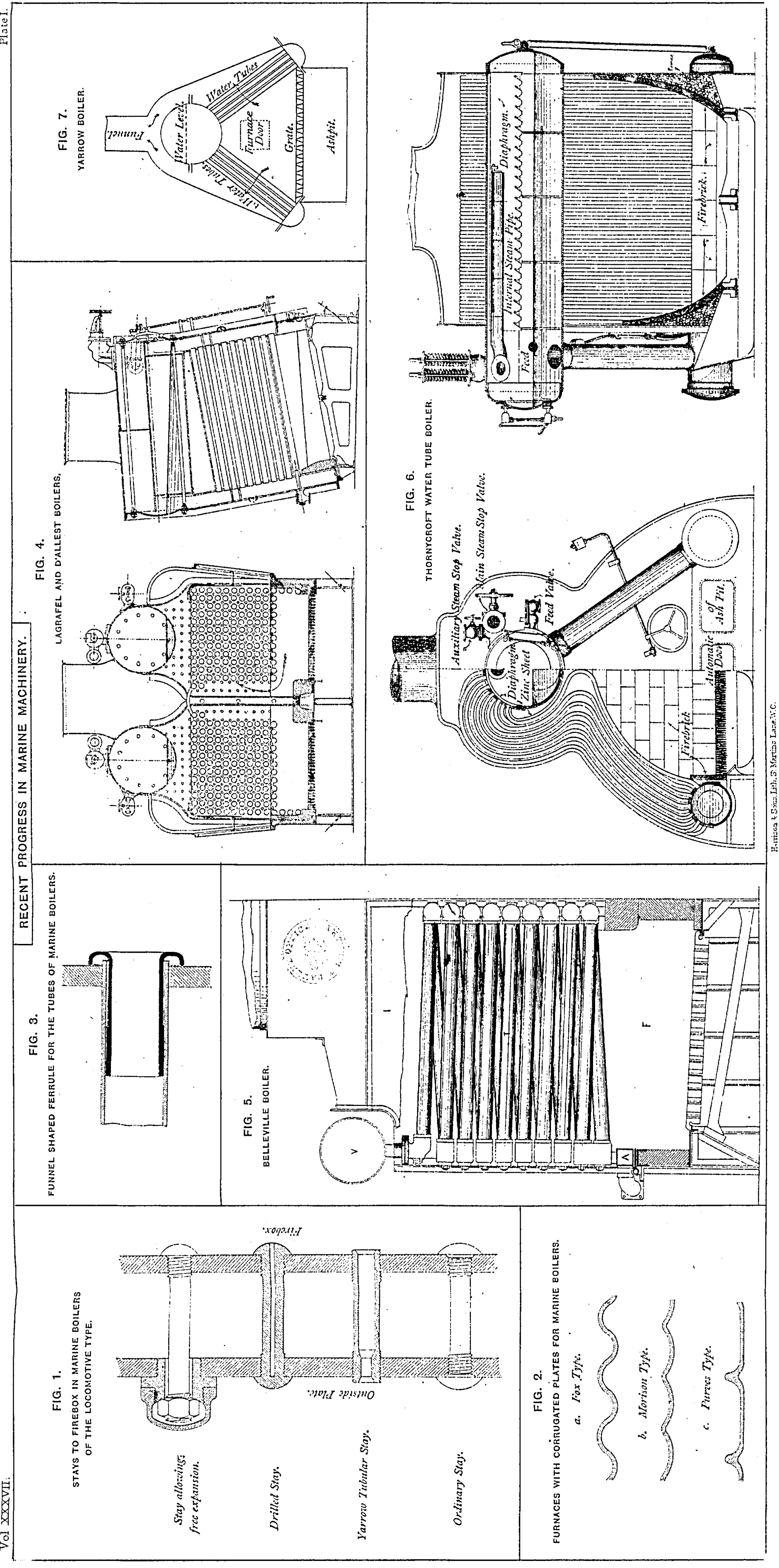


may be less exposed to the direct impact of the flame. To the same ond it is usual to hare diaphragms of fre-brick corresponding with the fire-bridge, so as to causo the flame to make a longer circuit before arriring at the tubo plate.

The importance of preventing the direct impact of the flames on the heating surfaces lias been well shown by Dr. Fred. Siemens, in his exccllent work, "Now Mlethod of Heating with Freo Derelopment of Flame." It is necessary, however, not to go too far in this direction, at least in boilers of tho locomotire type, since by lengthening the furnace the difference between the expansion of the internal hateral walls and tho corresponding parts external to the furnace is augmented, and, in consequence, the deformation thus caused throw's a great strain on tho stays supporting them, with the result that these are often carried away. This defect is one of frequent occurrence in locomotive boiles's, and to remedy it in somo measnre various expedients have been resorted to. lst. Drilling the stajs nearly through in tho direction of the axis, so that when one is ruptured tho slight escapo of water which takes place through the end gires evidence of the fact and shows which is the defective stay which must be replaced. 2nd. Allowing freo expansion at the outer stays to the furnace plates, where the expansion is most felt. 3rd. Giving more elasticity to the stays by turning them down in the central part to the diameter of the bottom of thread of the screwed conds.

Fig. 1 shows an ordinary stay, one which allows of frec expansion of the plates, and one of the drilled stays. None of these precautions are necessary for the stays to the crown of the furnace, because, by reason of their length, they can adapt themselves readily to follow the deformation and relative displacement of the sarts which they connect. The crown of the furnace in locomotivo and of the combustion chambers in ordinary marine boilers is supported by vertical stays connected cither to the shell of the boiler or to strong trarerses supported by the sides of the furnace or combustion chamber. The lirst system is generally followed in marine boilers of the locomotive type, and is also sometimes used in the ordinary type. It has the advantage that it relieves the sides of the furnace or combustion chamber of all strains due to the rertical pressure of the stcam on the crown, but with the defect that it makes the boiler inaccessible where these stays are fitted, and increases tho resistance to frec expansion of the furnace or combustion chamber. For these reasons many manufacturers prefer the traverso supports. In the same figare (Fig. 1) is shown one of the tabular stays, an idea of $\mathrm{Mr}$. Yarrow's, to admit of the stays themselres being replaced from inside the furnace. It has also been proposed to corrugate the crown of the furnace in the locomotive type in order to strengthen them and at the same time give them more freedom of expansion, bat as yet this iden has not been carried out in our Nays. In ordinary boilers with return tubes the furnaces are almost always corrugated to gire them the necessnry strength without unduly increasing the thickness of the plates. With respect to this, Mr. A. Blechynden, in 
his " Rovicw of Marine Fnginecring in the last Decade," read at the Institation of Jiechanical Enginecrs in 1891, expresses himself thas: The internal conductivity of tho metal for heat relatively to the absorbing and emitting power of its surface being very great; it would not appear to bo injudicious to mako the plates thicker in order to strengthen them withont making thern corrugated, and, in fact, there are makers of marine engines who havo used plates for furnaces of $20 \mathrm{~mm}$.thickness with mach success. Howerer, tho rules of the Board of Trado limit this thickness to $16 \mathrm{~mm}$. The rarious systems of corrugation aro sliown in Fig. 2 , and it is not yet certain which of them merits the preference. $A$ late improvement has been made in the furnaces to make them removable or interchangeable, as it is considered that in modern boilers the farnaces are more subject than othier parts to injury and detcrioration, so that the importance of making them easily renewable can be understood.

Successive Combustion Chambers.-Mr. F. TV. Tebb, engineer of tho London and North Western Railway, considering that the heating surface of tho tubes has its maximum efficiency at tho ends nearest the furnace, whero a length of $30 \mathrm{~cm}$. produces an craporation equal to that produced by the whole remaining length of the tube, and considering besides that, beyond the tube in the smoke-box, where tho gases meet beforo ascending the funnel, if the combustion is much forced, as it generally is in locomotives, it frequently happens that the gases remaining unconsumed and becoming mixed with air, aro ignited and a second combustion is prodnced, which is not only useless, but injurions; the idea occurred to him to divide the tubes into two parts about tho centre of their length, and to interposo between tho two parts another combustion chamber, whero the gases from tho first collection of tubes could mix, and ignite if unconsured, giving up the beat to the walls of this combustion thamber and to the second rows of tubes beforo finally escaping to tho smoke-box and funnel. The interposition of this second combustion chamber between the two nests of tubes would also have the effect to divide between four tube plates, instead of two only, the longitudinal expansion of the tubes, and so lessen one of tho causes of the frequent leaks which take place at the junction of the tube and tube plate. This idea, which has given good results in practice, as it would appear from the experiments which have been mado with a locomotive boiler, might probably bo applied with advantage not only to marino boilers of the locomotiro typo and direct tubo or gunboat type, but also to ordinary return tube boilers. With the application of tho successive combus. tion chambers, one of the principal causes of leaks tabes, however, still remains, that is to say, the relatively unequal expansion and de: formation which takes place at tho tobe ends, and the corresponding holes in the tube plate, cansed by tho different variations of temperature and the different strains to which thoso parts are subject, and which they must obey; on this point I have moro to say further on.

Tube Plates. - The tube plates are about the best supported of any of th internal parts of the boiler, the tabes independent of the stays 
giving them much support. For this reason it does not, seem necesgary that they should be thick in order to withstand the internal pressure of the boiler, and sinco their flexibility and facility which which they are traversed by heat and follow tho variations in tenpernture which takes place in tho tubes is the greater the less their thickness, and the nearer this thickness approximates to that of tho tubes, it would appear necessary to limit this thickness to that required for a good hold of tho tubes themselves, and the stay tabes. Mr. Yarrow, in his cornmunication abovo cited, gives much inıportance to this point, and gives it as bis opinion that the tube plates should not have a greater thickness than $12 \mathrm{~mm}$. It is probable that this rule may be gradually accepted by all, but for the present it is the practice not to go below $15 \mathrm{~mm}$. for the thickness of tube plates. For the same object, to facilitate the passage of lieat and the uniformity of temperature between the tubes and the tube plates, Mr. Yarrow belioves that the tubo plates should be of copper instead of iron, and, in support of his opinion, quotes the results of direct experiments made by himself and of experienco with bis boilers in torpedo-boats and locomotives. It may be that $\mathrm{Mr} \mathrm{r}$. $\mathrm{Y}_{\text {arrow }}$ is correct in his views, and that tube plates of copper are preferable to thoso of stecl in boilers of torpedo-boats, which aro not called on to mako long voyages or to remain long at sea; but it is doubtful if this would bo the ease in ships destined to remain a long time on activo service, liable to be kept far from a repairiug station, and to suffer rougher treatment than the former. In these latter boilers, galvanic action between the copper and iron might be the cause of considerable wear, whilst the sediment which rould form on the tube plates would soon cause the superiority to disappear as regards the conductivity for heat, oper the ordinary tube plates of iron or steel. Mr. Yarrow is also against the employment of stay tabes, whicly in his opinion, whilo unnecessars, because the tubo plates are well supported by the ordinary talies, they render the tube plates less free to yield to tho expansion and distortion of tho ordinary tubes, and for this reason aggravate the defects arising from these changes. If stays must be fitted, according to Mr. Yarrow, thoy should be equal in thickness and quality of metal to the ordinary tubes, so that they may expand and contract to the samo extent as these. Tho opinion of Mr. Yarrov finds mach support in the fact that boilers of the locomotivo type, both in locomotives proper and on board ship, have no stag tubes, and no defects have as jet occurred that can be properly attributed to their absence, while stay tubes which have been fitted in boilers with singlo combustion chambers on board ships, as the "Barmcouta" and other's in the English Nary, have not prevented serious leaks at the tubes and tule plates, which have cansed such alarm and distrust of this type of boiler. With less reason would stay tubes be necessary in marine boilers with separate combustion chamber to each furnace, since in this case the tube plates aro small and well supported at their perimeter by tho sides of the combustion chnmber. It is diff. calt, however, to understand that, while few object to the absence of the stay tubes in the locomotive type, verg few indeed will aceept of 
their suppression in ordinars boilers, which are still constructed with stas tubes as formerly. MIr. Yarrow, always in agreement with his principle to gire to the different parts of the boiler sufficient freedom to adapt themselres to the variations in temperature to which they are subject, also condemns the practice of fitting stajs, stay tubes, or eren ordinary tubes, too closely to the angles of the combustion clanmber, and suggests, if stays are fitted in these parts, they should be so fitted as to allow of free expansion, as hefore mentioned, in speaking of the furnace stajs of locomotive voilers. Since one of the principal causes of leaks at the tube plates around the tube cnds is the too high temperature to which these parts are exposed under forced draught, it has been endearoured to prevent this by applying a shicld in front of the tube plate, which, while it does not prevent the passage of the gases and their ingress into the tubes, will protect the tube plate and the ends of the tubes from the heat of the farnace.

Tr. Normand, the renowned torpedo-boat manufacturer, has carried out this idea for his torpedo-boat boilers with great success, applying at the mouth of each tube a funnel-shaped ferrule much rounded over at the projecting lip, which protects the tube-plate and facilitates the entry of the gases into the tubes. These ferrules have also given good results in the ordinary donble-ended boilers with common combustion chambers on the Fuglish cruiser "Barracouta," which gare so mach trouble on her first trials under forced draught without these ferrules, and more recently in other ships in the same Nars. In our Servico these ferrules will be gradually applied to all boiler's destined to work under forced draught. Fig. 3 shows the most recent type of fannelshaped ferrule adopted in the English Nary. Ferrules of cast iron, iron and mild steel, liare been tried : the best results as regards resistance to the action of the fire apperis to have been obtained with the latter material.

I'ules.-In modern marine boilers with engines fitted with surface condensers, by which internal incrustation is in gieat part climinated, a frequent removal of tho tubes is not necessarr, and they aro genernlly made of iron or mild steel, whilst formerly they were made of brass. In farour of this change is the reduction in cost of the tubes, and greater uniformity of material in the boilers, by which the differences of expansion are reduced, and consequentls its bad effect on the hold of the tubes on the tabe plates. On this point it would appear by recent experiments that iron tubes are preferable to those of steel, and there are, in fact, well known manufacturers who use iron tubes exclusively for marine boilers, in spite of their inferiority in point of strength, tenacity, and malleability to steel tubes.

Mr. A. Blechyuden, engineer at Barrow-in-Furness, is of this opinion, and he has carried out some interesting experiments on the belnviour of iron and steel tubes when they aro succes. sivels exposed to alternate heating and cooling at their junction with the tube plate. But one kind just as much as the other has the serious defect, esprcially for war-ships which must often remain for a long tiwe inactire, that they corrode rapidly, also 
when the boiler is laid up. 'This decay takes the form of a pitting corrosion, which is set up in the tubes, and being very thin they soon become perfornted, and so a slip may be rendered angerriceable whose boilers bat a short time before liad been considered in good condition. Perhaps this difficulty may be overcome by using tubcs of nickel steel, which is not very liable to corrosion. It is a good practice to make the tabes slightly larger in diameter at the smoke-box end, to facilitate their remoral when it becomes necessary to renew them. If this is clone the tubes mas be ordered with the diameter at the ends slightly in excess of the diameter of the holes in the tube plate, and the tubes then ground to fit exactly; in this way there is no necessity to use any excessive force with the mandril to fix them securely in the tube plate.

When the employment of the fannel-shnped ferrules has becomo general it will also be advisable to enlargo the tubes at the fire-box end, in order that these ferrules may be applied withont unduly restricting tho section for the passage of the gases. In the boilers of torpedoboats, and also in ordinary marine boilers, the tubes have been serewed into the tube plates in oriler to lessen the risk of leakage at this part; but with the employment of the new ferrales this will not be necessary.

Disposition of the 'T'ubes, and Space betuecn them.-Mach has been said on the best arrangement of the tubes to facilitate the circulation of the water, and the free escape of the steam between them, and of the space which should exist between them in proportion to their diameter. Somo prefer a lozenge-shaped, others a rectangalar, arrangement. The, latter uppears the best adapted to favour the circulation, and is generally observed in ordinary cylindrical boilers with return tubes. The lozenge-shaped disposition has the advantage that it utilizes the space better; for this reason it is frequently adopted for the locomotive typo of boiler, in which, the cornbustion being very active, it is necessary to provide a large hèating surfaco in proportion to grate surface. The lozenge is usually elongated, and it is preferablo to arrange the tubes so that the major axis of the lozenge is vertical. It is considered good practice to have a space of not less than $25 \mathrm{~mm}$. between the tubes, and this rule is generally followed in ordinary marine boilers; but it is doubtful, in eny opinion, whether either the disposition of the tubes or the interval between them has so much infuence as many believo on the good circulation of the water, or at lenst on the good hold of the tabes, siuce in the boilers of torpedo-boats of the "Schichau" typo very good results have been obtained as regards the hold of the tubes, although they are arranged lozenge fashiou, with an interval of only 9 to $12 \mathrm{~mm}$. It must in justice be added, howerer, that these tubes, instead of being simply expanded, are screwed into the tube plate at the furnace cnd.

Serve Tubes. - With the object of extracting more heat from the gases in their passage through tho tubes, MI. Serre has employed tubes with a system of internal radial ribs, except for a short space at each end, where the tubes have to be expanded into the tube plates. Naturally these ribs offer a resistance to tho passage of 
the gases, and increase the weight of the tubes; but these incon. veniences may be compeusated for by the better utilization of the heat; by tho experiments made, it would appear that thero was an increase of about 10 per cent. efficiency in this particular.

Water-Thbe Boilers.-Ono of the methods by which the dificulties inherent to the use of forced draught, can be radically solved is, no doubt, the employment of water-tube boilers. In these boilers, and more especially in the more perfect of them, the various elenients of which they aro composed are disposed and combined in such a way that they aro free to expand and contract under the influences of the variations of temperature; and, besides which, the extremities of the tubes where they aro connected to tho other parts of the boiler are not exposed to the direct action of the fire: so that the risk of injury to this union from the abore cause is avoided. Ihere already exist a great mnny types of these boilers, of which I will only enumerate the principal.

1. Boilers with a collection of straight tubes slightly inclined to the horizontal, and which connect two opposite plane and rectangular chambers of water, or two columns of water, which communicate with the stenm chamber above. Of theso types neo the "d'Allest" (Fig. 4), used in rarious ships of the French Navy, and the "Towno" boiler with transverse crossed tubes.

2. Boilers with collections of tabes, forming so many independent zigzar windings, in directions slightly inclined to the horizontal, and which lead from a watcr chamber at the lower part to an external stcam chest aborc, and having an external circulating tuba between these two clinmbers. Of this type are the "Bellerille" (Fig. 5) and the "Temple" boilers, used in the Freuch Nary.

3. Boilers with a continaous scrpentine tube, which haro for prototype the American "Uerreschoff" boiles, used in steamboats.

4. Boilers with concentric tubes, that is, in which the water tubes nre traversed by tubes of smaller diameter, through which the products of combustion pass, and which serre as stajs to the sides of the water chamber. The "Bartlett" boiler belongs to this class.

5. Boilers with collections of tubes leading upwards in straight or curved lines, and connecting two lateral water chambers below to a central stegm chamber abore, and having exterior circulating tubes connecting the water chambers to the steam chest. The "Thornycroft" (Fig. 6), the "Yarrow" (Fig. 7), and tho "Norwand" boilers belong to this type.

Theso boilers havo been used with great success on board torpedoboats; the last named is rery similar to the "Yarrow" boiler. The wnter-tube boilers have threo great advantages, and these are extreme lightness; with scme of them it has been possible to obtain $1 C 0$ h.p. per ton of boiler, including the weight of water; great sccurity against explosion; less risk of injury or leakage when used at maximum power. Against these adrantages, water-tube boilers are not so casily managed as ordinary koilers, especially if thero aro a considerable number of them on bcard the same ship, in consequence of the large and ropid.rariations in the steam pressure and 
water lercl to which thes are subject; they are also less easily repaired in case of any damago to the tabes of which they are com. posed. Besides this, they requiro that distilled water, exclusively, should be used for them; and, their maximnm power being as yet limited to about 1,000 h.p., a much larger number of them are required on board ship in comparison with what wonld be required if boilers of the ordinary t5pe were employed; whence tho difficulty of management and tho probability of dofects arising are relatively grcater.

From the larger number of mater-tube boilers required on board a ship it would happen, in certain cases, that the space required for them would be grenter than would suffice if ordinars boilers of the locomotive type were used. But marine tubulous boilers are, ono mas say, still in their infancy, and it is very probable that, in time, they may be brought to such perfection as to mako them in all respects preferable to the boilers now in use.

\section{(To be continued.)}

Note.-It is worthy of note in the above article that Mr. Normand is credited with the introduction of the protectivo ferrule for the ends of the boiler tubes, and it appears to be inferred that MI. Normand's plan has been copied by the British Admiralts; whereas I believe the Admiralty ferrule, a section of which is shown in Fig. 3 , is entirels an original idea due to an Officer at present serving at the Admiralty. It is also worthy of note that the form of protectivo ferrule proved to be the most effective in Fingland is at once made familiar to the nflicers of the Italian Navy through the medium of a uaral teclnical journal. An English naral technical journal which would collect and reproduce all published information with descriptive sketches, relating to inventions and improvements introduced into forcign naval serrices, would supply a great want, and is almost a necessity to all Oficers of our own Service who wonld kecp themselves at the head of their profession. No doubt the Foreign Section of the R.U.S.I. Journal could be so developed as to supply this much needed information in a form most acceptable to busy ruen, and there are hopefal indications in its pages lately of a rapid growth in this dircction.-The Traxshator. 